\title{
The Effect of Family Literacy Program Towards the Improvement of Parental Involvement in Early Childhood Education
}

\author{
Hayuni Husni ${ }^{1, *}$ Lokot Daulay ${ }^{1}$ Salman Hasibuan ${ }^{1}$ \\ ${ }^{1}$ Development Center for Early Childhood Education and Community Education, North Sumatra, Indonesia \\ *Corresponding author. Email: hayunihusni@gmail.com
}

\begin{abstract}
The aims of the research are: 1) to raise parents' awareness and improve their participation at school and home; 2) to empower children's character; 3 ) to develop children's academic attainments. The research used correlational method. The samples of the research are parents from private early childhood education school of Darul Ilmi Murni Deli Serdang, Indonesia. The findings: 1. Family literacy programs applied by parents are effectively increased parental involvement neither at schools nor at home; 2 . The Correlation Coefficient value is known to be 0.913 greater than $r$ (table) 0.349 meaning that there is a significant correlation between the family literacy program and improvement family involvement at school. The Family Literacy Program and the Improvement of Family Involvement at school are classified as near perfect because they are in the $>0.91$ range.

Keywords: Parental involvement, family literacy, early childhood education, North Sumatra
\end{abstract}

\section{INTRODUCTION}

Family involvement in the process of the implementation of children's education is a must because family is the first and foremost educator. Provision of knowledge and skills for families related to education and childcare needs to be done systematically in order to build awareness of parents to be involved in the process of children's education, so the family is able to become a strong bull in protecting children from various social problems faced.

Based on the result of preliminary studies/explorations conducted in Langkat Regency, Deli Serdang Regency and Serdang Bedagai Regency, North Sumatra Province, it is obtained that parental awareness in instilling literacy culture in the family was still very low (47.22\%). Parents stated that they had not done the activities such as accompanying children to learn at home, reading book stories/ storytelling to children, facilitating children's book references at home as a routine that needs to be done at home. As we know that participating in reading books beside children and accompanying children to learn is an important activity for parents to do. Parents are a "literacy model" for children, in exemplifying how parents become the first role models of reading activities. Pomerantz (2001) says that parents who become models in literacy through writing and reading activities have a positive impact on children's literacy development.

Experts have recognized that the family has a big influence on children's language development and literacy. The engaging parents or family members in developing children's literacy culture done with various activities shows that there is an influence in children's preparation to the education field, increasing the children's ability to complete tasks at school, developing children's motivation to love reading (Crawford, Zygouris- Coe, 2006; HiattMichael, 2001).

A good reading ability from early age as a form of literacy is a strong foundation for the development of literacy and the key of the future academic success of children (Hamilton, Hayiou-Thomas, Hulme, Snowling, 2016). Moreover, the concept of 21st century literacy has developed so much that literacy is not only reading and writing, but also listening and speaking (Kiiveri, Määttä, Uusiautti, 2012).

It is true that contradictory description is a problem faced by the Indonesian people. The survey results of some institutions released the data that Indonesia is currently having a crisis of interest in reading and literacy. Program for International Student Assessment (PISA) in 2015 showed the data that the literacy index or reading level of Indonesian students ranks 64 th out of 76 countries. In fact, UNESCO in 2012 showed the data that a reading data index of Indonesian society 0.001 . It means that from 1,000 people, only one person has an interest in reading.

Literacy begins to grow from within the family as the first informal institution to provide educational services to children long before children began to know reading and writing at school. Even children's cognitive development is also formed through the process of children's participation in social activities with family members that support the formation of a variety of children's understanding related to 
various skills in recognizing cultural devices and activities in the family (Rogoff, 1990). The particular skills children have and the orientation they develop are also rooted in the history and cultural activities of the community (family) where children interact.

Regulation of Minister of Education and Culture Number 30 of 2017 (Minister of Education and Culture of Indonesian Republic, 2017) concerning family involvement in the implementation of education, explained in Article 7, that one form of family involvement that can be done is an effort that can encourage literacy culture.

The development of family literacy until the end of it is also expected to give an impact on the fulfillment of National Standards for Early Childhood Education, especially in the fulfillment of management standards that are reflected in the integrative holistic program.

Targeting family units as an intervention program is an effective approach to improving family literacy culture. Engaging parents in improving literacy culture is expected to be able to solve the problem of low level family literacy and as an effort to suppress the rate of reality that the literacy is weak in the family tends to be repeated in the next generations in the family.

\section{REVIEW OF LITERATURE}

\subsection{Family Literacy}

At the beginning, literacy is conventionally defined as the ability to read and write. In order to be a literate individual, one should have good mastery on knowledge of letters as well as knowledge of the environment to understand well what is being read (Snow et al., in Wasik, 2004). As the dynamics of life develops in terms of economic, social, and political aspects, experts finally gave a broader concept of the definition of literacy (Kestle, 1985). In the mid-20th century, scientists from the scientific background of psychology, economics, language, sociology, anthropology and history finally gathered to share ideas through heated debates to produce a theoretical understanding of literacy (United Nations Educational, Scientific and Cultural Organization [UNESCO], 2005).

In general, experts state that there are a lot of skills (literacy) that can be developed in order to help individuals to achieve successful life in the future, including how to support individual success through family institution or known as family literacy, also.

The existence of parents is believed to be so important in understanding children's literacy development, because they have the special opportunity to interact with their children with language and various books every day (Timmons \& Pelletier, 2015). The basic conception of family literacy that is built is the cognitive development of children formed through interaction with partners who have more knowledge (Caspe \& Kennedy, 2013). Pelt (2016) explains that family literacy is a type of literacy in education that emphasizes and makes reading and writing to be a part of the inherent activities in the family.

\subsection{Family Involvement in the Implementation of Early Childhood Education}

A report published by the Australian Research Alliance for Children \& Youth for the Family-School and Community Partnerships Bureau found an evidence of the benefits of positive parents' involvement and strategies that could be considered by policy makers in facilitating such involvement.

The report contains a synopsis of literature related to parents' involvement, both at home and at school. Based on the evidence in the literature, the approaches that have the most influence and impact on student learning outcomes can be identified. Remembering the clear benefits of positive parents' involvement in student learning activities which is indicated by increased academic achievement, welfare and productivity, so the report concludes that resources and effectively initiative parental involvements are really needed even for educational reform and Australia in the future.

Melhuish et al., (2008) stated that engaging parents in the early childhood education has a significant influence on educational achievement, and continues to do so in a teenager and adult. This statement is supported by the opinion put forward by Goldman (2005) that the quality and content of engaging fathers is more important than the quantity of time fathers spend with their children. Families can also provide various benefits for parents and children including improvements in reading, writing and arithmetic and greater parental trust in helping their children at home.

\section{RESEARCH METHODOLOGY}

\subsection{Research Method}

In this study, the approach used is a quantitative approach. This research method is correlational research in which a study aims to find out how two or more variables are related. This study aims to establish the degree of correlation between two or more variables expressed by the correlation coefficient (Soewadji, 2012). 


\subsection{Research Place}

The study was conducted at Darul Ilmi Murni Private Kindergarten Plus, Deli Serdang Regency, North Sumatra Province, Indonesia.

\subsection{Research Subjects}

The subjects in this research and development were 30 parents at the Darul Ilmi Murni Kindergarten education unit.

\section{RESEARCH HYPOTHESIS}

The hypothesis of this research is as follows:

Ho : There is no effect of the Family Literacy Programs towards Improving of family involvement in the implementation of early childhood education at Plus Private Darul Ilmi Murni School.

Ha: There is effect of the Family Literacy Programs towards Improving of family involvement in the implementation of early childhood education at Plus Private Darul Ilmi Murni School.

\section{RESULTS AND DISCUSSION}

\subsection{Cross Tabulation Analysis}

1) Cross Tabulation Analysis between Activities Taking Children On First Day of School Motivating Me To Be Involved In The Education Process Of Children * I Am Actively Involved In Activities Organized By Parents' Association

Table 1 Chi-square tests

\begin{tabular}{|c|c|c|c|}
\hline & Value & df & Asymptotic Significance (2-sided) \\
\hline Pearson Chi-Square & $30.000^{\mathrm{a}}$ & 3 & .000 \\
\hline Likelihood Ratio & 23.560 & 3 & .000 \\
\hline Linear-by-Linear Association & 16.836 & 1 & .000 \\
\hline N of Valid Cases & 30 & & \\
\hline
\end{tabular}

Based on the "Chi-Square Test" in Table I, the Asymp values is obtained. Sig 0.00 is smaller than 0.05 . So the analysis and interpretation of the data is that there is a significant relationship between the activities of taking the child on the first day of school motivating me to be involved

Table 2 Chi-square tests in the process of children's education in which I am actively involved in activities organized by the parents' association. 2) Cross Tabulation Analysis between Parent's Association Helps Increase My Engaging in Implementation of Children's Education at School and at Home * After Joining the Association, I often Talk About Education and Development of Children With other Parents.

\begin{tabular}{|c|c|c|c|}
\hline & Value & df & Asymptotic Significance (2-sided) \\
\hline Pearson Chi-Square & $22.700^{\mathrm{a}}$ & 6 & .001 \\
\hline Likelihood Ratio & 20.844 & 6 & .002 \\
\hline Linear-by-Linear Association & 9.589 & 1 & .002 \\
\hline N of Valid Cases & 30 & & \\
\hline
\end{tabular}

Based on the "Chi-Square Test" in Table 2, the Asymp value is obtained. Sig 0.00 is smaller than 0.05 . So the analysis and interpretation of the data is there is a significant relationship between the Parents' Association helping increase my engaging in the implementation of children's education at school and at home, and after joining the association, I often talk about the education and development of children with other parents.

3) Cross Tabulation Analysis between Parents' Classes Helps Me Understand Childcare Problems * After Attending Parents' Classes, I often Accompany Children Learn At Home more. 
Table 3 Chi-square tests

\begin{tabular}{|l|l|l|l|}
\hline & Value & df & Asymptotic Significance (2-sided) \\
\hline Pearson Chi-Square & $24.002^{\mathrm{a}}$ & 6 & .001 \\
\hline Likelihood Ratio & 25.182 & 6 & .000 \\
\hline Linear-by-Linear Association & 6.154 & 1 & .013 \\
\hline N of Valid Cases & 30 & & \\
\hline
\end{tabular}

Based on the "Chi-Square Test" in Table 3, the Asymp value was obtained. Sig 0.01 is smaller than 0.05 . So the analysis and interpretation of the data is that there is a significant relationship between parents' classes helping me understand childcare problems and after attending parents' classes, I often accompany children to learn at home more.

Table 4 Chi-square tests
4) Cross Tabulation Analysis Between Inspiration Class Activities that is useful to introduce and give inspiration to children for varieties of professionals that can be chosen later *I'm Willing And Confident to Perform in Inspiration Classes.

\begin{tabular}{|c|c|c|c|}
\hline & Value & df & Asymptotic Significance (2-sided) \\
\hline Pearson Chi-Square & $4.593 \mathrm{a}$ & 4 & .332 \\
\hline Likelihood Ratio & 5.188 & 4 & .269 \\
\hline Linear-by-Linear Association & 3.920 & 1 & .048 \\
\hline N of Valid Cases & 30 & & \\
\hline \multicolumn{2}{|l}{ a. 7 cells (77.8\%) have expected count less than 5. The minimum expected count is .50 }
\end{tabular}

Based on the "Chi-Square Test" in Table IV, the Asymp value was obtained. Sig 0.32 is greater than 0.05 . So the analysis and interpretation of the data is there is no significant relationship between the understanding of parents about the use of inspirational classes for children

Table 5 Chi-square tests with the willingness of parents and confidence to perform in the inspirational class.

5) Cross Tabulation Analysis Between Parents' journals helping me encourage a culture of literacy at home * I was involved in implementing a parental journal at home

\begin{tabular}{|c|c|c|c|}
\hline & Value & df & Asymptotic Significance (2-sided) \\
\hline Pearson Chi-Square & $42.312 \mathrm{a}$ & 6 & .000 \\
\hline Likelihood Ratio & 32.039 & 6 & .000 \\
\hline Linear-by-Linear Association & 13.266 & 1 & .000 \\
\hline N of Valid Cases & 30 & & \\
\hline
\end{tabular}

a. 8 cells $(66.7 \%)$ have expected count less than 5 . The minimum expected count is .20

Based on the "Chi-Square Test" in Table 5, the Asymp value was obtained. Sig 0.00 is smaller than 0.05 . So the analysis and interpretation of the data is there is a significant relationship between parental journals helping me to encourage literacy culture at home in which I was involved in implementation of parental journals at home. 


\subsection{Correlation Analysis}

Table 6 Correlations

\begin{tabular}{|c|c|c|c|}
\hline & & $\begin{array}{c}\text { Family Literacy } \\
\text { Program }\end{array}$ & $\begin{array}{l}\text { Family Involvement in the } \\
\text { Implementation of ECE }\end{array}$ \\
\hline \multirow{3}{*}{ Family Literacy Program } & Pearson Correlation & 1 & $.913 * *$ \\
\hline & Sig. (2-tailed) & & .000 \\
\hline & $\mathrm{N}$ & 30 & 30 \\
\hline \multirow{3}{*}{$\begin{array}{l}\text { Family Involvement in the } \\
\text { Implementation of ECE }\end{array}$} & Pearson Correlation & $.913 * *$ & 1 \\
\hline & Sig. (2-tailed) & .000 & \\
\hline & $\mathrm{N}$ & 30 & 30 \\
\hline
\end{tabular}

Based on the result of data processing of Family Literacy Program (X) and Family Involvement in the Implementation of Early Childhood Education (Y) as shown in Table VI, the following analysis can be given:

1) The Correlation Coefficient value is known 0.913 greater than $\mathrm{r}$ (table) 0.349 , it means that there is a significant correlation between the Family Literacy Program and Family Involvement in ECE. The Family Literacy Program and Family Involvement in ECE are categorized as near perfect relationship levels because they are in the range > 0.91 range.

2) Family Involvement in Implementation of ECE is high.

\section{CONCLUSION}

1) The implementation of the family literacy program at the Darul Ilmi Murni Plus Private Kindergarten has an impact on increasing parents' involvement in the implementation of early childhood education. The family literacy program can also create a conducive educational ecosystem through several stages of activities carried out starting from taking the child on the first day of school, homeroom meeting with parents, parent classes, inspirational classes and year-end class performances. And the implementation of most of the programs were suitable based on the planning that has been arranged together between the school and parents' association.

2) Parental journal is a tool / instrument used by parents as a guide to implement literacy culture from an early age that starts from the home environment to support the strengthening of literacy in the family. It also turned out to have a positive impact on parents and children, which is reflected in the activities carried out by parents in the family environment with children.

\section{REFERENCES}

Caspe, M., Seltzer, A., Kennedy, J. L., Cappio, M., DeLorenzo, C. (2013). Engaging families in the child assessment process. YC Young Children. 68(3), 8.
Crawford, P. A., \& Zygouris-Coe, V. (2006). All in the family: Connecting home and school with family literacy. Early Childhood Education Journal, 33(4), 261-7.

Goldman, R. (2005). Fathers' involvement in their children's education: A review of research and practice. London: National Family and Parenting Institute.

Hamilton, L. G., Hayiou-Thomas, M. E., Hulme, C., \& Snowling, M. J. (2016). The home literacy environment as a predictor of the early literacy development of children at family-risk of dyslexia. Scientific Studies of Reading, 20(5), 401-419.

Hiatt-Michael, D. B. (2001). Schools as learning communities: A vision for organic school reform. School Community Journal, 11(2), 113-127.

Kestle, D. R. (1998). Implementing signal support principles on the battlefield of the future. Army Command and General Staff Coll Fort Leavenworth Ks School of Advanced Military Studies.

Kiiveri, K., Määttä, K., \& Uusiautti, S. (2012). Literacy matters-the $21^{\text {st }}$-century children's opinions on the significance of literacy. literacy, 49, 27.

Melhuish, E. C., Sylva, K., Sammons, P., SirajBlatchford. I., Taggart, B., ...Malin, A. (2008). Preschool influences on mathematics achievement. Science, 321(5893), 1161-1162.

Minister of Education and Culture of Indonesian Republic. (2017). Regulation of Minister of Education and Culture Number 30 of 2017. Jakarta: Minister of Education and Culture of Indonesian Republic

Pomerantz, F. K. (2001). Parent-child literacy projects. In HiattMichael, D. Promising practices for family involvement in schools (pp. 59-84). Greenwich: Information Age. 
Rogoff, B. (1990). Apprenticeship in thinking: Cognitive development in social context. Oxford: Oxford University Press.

Soewadji. (2012). Pengantar metodologi penelitian. Jakarta: Penerbit Bumi Aksara

Timmons, K., \& Pelletier, J. (2015). Understanding the importance of parent learning in a school-based family literacy programme. Journal of Early Childhood Literacy, 15(4), 510-532.

United Nations Educational, Scientific and Cultural Organization (UNESCO). (2015). Education for all: Literacy for live. Paris: United Nations Educational, Scientific and Cultural Organization Publishing

Van Pelt, M. (2016). Book review: Dafna Lemish: Children and Media-A Global Perspective. Journal of Youth and Adolescence. ISBN: 978-1-118-78706-9, 2458-2460.

Wasik, B. H., \& Herrmann, S. (2004). Family literacy: History, concepts, services. In Handbook of family literacy (pp. 23-42). Routledge. 